\title{
Flow and Scour Analysis Around Monopole of Fixed Offshore Platform Using Method that Couples Computational Fluid Dynamics and Discrete Element Method
}

\author{
Seongjin Song $\mathbb{(}^{*}$, Wooyoung Jeon ${ }^{\circledast^{*}}$ and Sunho Park ${ }^{\circledR *}$ \\ "Department of Ocean Engineering, Korea Maritime and Ocean University, Busan, Korea \\ CFD-DEM 연계기법을 활용한 고정식 해양구조물의 \\ 모노파일 주위 유동 및 세굴해석 \\ 송성진(* · 전우영* · 박선호®* \\ "한국해양대학교 해양공학과
}

KEY WORDS: Sediment transport 표사 이동, Scour 세굴, Computational fluid dynamics 전산유체역학, Discrete element method 이산요 소법, Monopole foundation 모노파일 기초

\begin{abstract}
When an offshore foundation is exposed to waves and currents, local scour could develop around a pile and even lead to structural failure. Therefore, understanding and predicting the scour due to sediment transport around foundations are important in the engineering design. In this study, the flow and scour around a monopole foundation exposed to a current were investigated using a method that coupled the computational fluid dynamics (CFD) and discrete element method (DEM). The open source computation fluid dynamics library OpenFOAM and a sediment transport library were coupled in the OpenFOAM platform. The incipient motion of the particle was validated. The flow fields and sediment transport around the monopole were simulated. The scour depth development was simulated and compared with existing experimental data. For the upstream scour hole, the equilibrium scour depth could be reproduced qualitatively, and it was underestimated by about $23 \%$.
\end{abstract}

\section{1. 서 론}

수심 $60 \mathrm{~m}$ 이하에 조성된 대부분의 해상풍력발전 단지는 고정 식 구조물로 설치되어 있다. 이러한 고정식 해양구조물은 구조 적 안정성과 비용적인 이유로 주로 근해에 설치되어 수명 기간 동안 한 곳에서 운용된다. 따라서 고정식 해상풍력발전기의 설 계 시 상부구조물의 하중을 안정적으로 지지할 수 있는 해상기 초구조물의 설치가 중요하게 작용한다. 고정식 해상풍력발전기 는 해저 지반과 해양 환경에 따라 여러 가지 설계요소를 고려 해야 한다. 그 중 세굴에 의한 침식 현상은 유체 흐름과 구조물 의 상호작용으로 기초구조물 주위의 해저 입자가 유실되는 현 상으로 정의할 수 있다. 세굴에 의한 침식은 터빈에 작용하는 큰 전복 모멘트를 견뎌야 하는 구조물의 안정성을 저하시키는 원인이며, 이에 관한 연구가 매우 중요하다. 고정식 해상풍력발
전기는 운용 기간이 점차 증가함에 따라 관련 세굴 문제에 대 한 연구가 지속적으로 진행되고 있다(Whitehouse, 1998; Sumer and Fredsoe, 2002). 특히, 고정식 해상구조물의 기초 중 가장 단 순한 형태인 모노파일 주위에서 발생하는 세굴 현상에 대한 실 험 및 수치적 연구가 주로 수행돼 왔다(Dargahi, 1989; Pang et al., 2016). 수치적 연구로는 전산유체역학(Computational fluid dynamics, CFD)을 사용하여 구조물과 유체 흐름의 상호작용으 로 발생하는 바닥 전단 응력계수를 통해 세굴의 정도를 추정하 는 방법이 있다(Park et al., 2017). 하지만 이는 해저를 구성하는 토양의 영향을 현실적으로 충분히 고려하지 못한다. 다음으로 Baykal et al.(2017)은 표사 이동 모델(Sediment transport model)을 적용한 형태학적 모델(Morphological model)과 전산유체역학을 결합하여 해저 지반의 형태학적 특성을 고려하였다. 형태학적 모델을 이용한 세굴의 예측은 정도 높은 결과를 나타내지만 유

Received 29 March 2019, revised 10 May 2019, accepted 13 June 2019

Corresponding author Sunho Park: +82-51-410-4329, spark@kmou.ac.kr ORCID: https://orcid.org/0000-0002-0388-2198 It is noted that this paper is revised edition based on proceedings of KOSMEE 2018 in Yeosu and ISOPE 2019 in Hawaii.

(C) 2019, The Korean Society of Ocean Engineers

This is an open access article distributed under the terms of the creative commons attribution non-commercial license (http://creativecommons.org/licenses/by-nc/3.0) which permits unrestricted non-commercial use, distribution, and reproduction in any medium, provided the original work is properly cited. 
체 흐름에 의한 영향을 단방향으로 고려하기 때문에 해저 지반 의 동적 특성을 전산유체해석에 반영하는데 어려움이 있다. 유 체와 지반의 상호작용을 고려하는 방법으로 이산요소법(Discrete element method, DEM)이 사용된다. 이산요소법에서 입자의 거 동은 입자들 간의 미소한 크기의 겹침을 허용하여 발생하는 반 발력에 의해 계산된다. 이러한 방법은 입자의 정확한 거동을 해 석할 수 있을 뿐만 아니라 간단한 충돌 모델을 이용한 많은 양 의 입자를 처리할 수 있는 장점이 있다. 따라서 유체 흐름에 의 한 입자의 거동을 고려하기 위해 이산요소법과 전산유체해석을 동시에 고려하는 CFD-DEM 연계기법이 필요하다. CFD-DEM 연계기법은 입자에 작용하는 유체의 영향과 유체에 작용하는 입자의 영향을 양방향으로 고려할 수 있다는 특징이 있다. 최근 에는 CFD-DEM 연계기법을 이용한 표사 이동 해석 연구가 진 행되어 오고 있다(Schmeeckle, 2014; Sun and Xiao, 2016).

Hur and Jeon(2011)이 LES(Large eddy simulation) 수치모델 이 용한 전산유체해석과 이산요소법(Cundal and Strack, 1979)을 결 합하여 불투과 잠제 전면의 세굴 및 퇴적 현상을 모의하였다. $\mathrm{Li}$ and $\mathrm{TaO}(2018)$ 는 CFD-DEM 연계기법을 이용하여 길쭉한 모양의 교각 주변에서 발생하는 정적 국부 세굴을 해석하였고, Yang et al.(2018)는 해저파이프라인 주변 2차원 세굴 특성을 해석하였다. CFD-DEM 연계기법을 이용한 연구는 활발하나 해저 지반을 구 성하는 엄청난 양의 개별 입자에 따른 계산 부하를 줄이기 위한 연구와 구조물 주위에서 교란된 유체 흐름에 의한 입자의 거동 및 침식 현상에 대한 연구는 아직 부족한 실정이다.

따라서, 본 연구에서는 CFD-DEM 연계기법을 이용하여 모노 파일 주위의 입자 거동과 유체 흐름을 해석하였다. 수치해석을 위해 소스코드가 공개되어 있는 라이브러리를 사용하였다. 입자 해석인 DEM을 위해 LIGGGHTS(LAMMPS improved for general granular and granular heat transfer simulations)과 $\mathrm{CFD}$ 해석을 위한 OpenFOAM이 사용되었다(Goniva et al., 2012).

\section{2. 수치 모델링}

\section{1 이산요소법(Discrete element method)}

이산요소법의 기본 개념은 Cundal and Strack(1979)에 의해 제시 되었다. 입자 간의 충돌은 Linear spring-dashpot 모델로 단순화하였 고, 개별 입자의 운동은 뉴턴 제 2 법칙으로 나타낼 수 있다. 입자의 병진 운동과 회전 운동에 대한 지배 방정식은 식 (1)-(2)와 같다.

$$
\begin{aligned}
& m_{p} \frac{d u_{p}}{d t}=\sum f_{p, p}+\sum f_{p, w}+m_{p} g+f_{p, f} \\
& l_{p} \frac{d w_{p}}{d t}=T_{p}+T_{p, f}
\end{aligned}
$$

여기서, 아래 첨자 $p$ 는 개별 입자를 나타낸다. 식 (1)은 입자의 병진 운동을 나타내며, 우변의 첫 번째 항부터 $f_{p, p}, f_{p, w}, m_{p} g$ 그리고 $f_{p, f}$ 는 입자 간 작용하는 힘, 입자-벽의 충돌에 의한 힘, 중력 그리고 유체-입자 상호작용 힘을 의미한다. 유체-입자 상 호작용으로 항력과 압력차에 의한 힘(Pressure gradient force) 그 리고 점성력을 고려하였다. 항력 모델로는 Koch and Hill(2001)
이 사용되었다. 식 (2)는 입자의 회전 운동을 나타내며, 입자 간 의 충돌에 의한 토크와 유체력에 의한 회전력 즉, 구름 마찰력 으로 나타낼 수 있다(Kloss et al., 2012).

\section{2 전산유체역학(Computational fluid dynamics)}

유체 영역의 해석은 비압축성 유체의 국소 평균화된 질량 보 존 방정식과 모멘텀 보존 방정식(Anderson and Jackson, 1967)을 사용하였으며, 입자의 움직임에 따라 변하는 셀의 유체밀도는 국소 평균화된 유체 영역의 부피분율 이용하여 고려하였다. 지 배방정식은 식 (3)-(4)와 같이 나타낸다.

$$
\begin{aligned}
& \frac{\partial \alpha_{f}}{\partial t}+\nabla \cdot\left(\alpha_{f} u_{f}\right)=0 \\
& \frac{\partial \alpha_{f} u_{f}}{\partial t}+\nabla \cdot\left(\alpha_{f} u_{f} u_{f}\right)=-\alpha_{f} \nabla \frac{p}{\rho_{f}}+R_{f, p}+\nabla \cdot\left(\alpha_{f} \tau_{f}\right)
\end{aligned}
$$

여기서, 아래 첨자 $f$ 는 유체 영역을 나타낸다. $\rho_{f}$ 는 유체의 밀 도, $\alpha_{f}$ 는 유체 영역의 부피분율, $u_{f}$ 와 $p$ 는 유체 속도와 압력을 각각 나타낸다. $\tau_{f}$ 는 점성 응력항을 나타내며 $R_{f, p}$ 는 유체-입자 간의 운동량을 나타낸다. $\alpha_{f}, \tau_{f}$ 그리고 $R_{f, p}$ 는 각각 식 (5)-(7) 과 같이 나타낼 수 있다.

$$
\begin{aligned}
& \alpha_{f}=1-\sum_{k=1}^{N_{p}} \frac{V_{p, k}}{V_{c}} \\
& \tau_{f}=\nu_{f}\left(\nabla u_{f}+\left(\nabla u_{f}\right)^{T}-\frac{2}{3} \nu_{f}\left(\nabla \cdot u_{f}\right) I\right. \\
& R_{f, p}=K_{f, p}\left(u_{f}-\left\langle u_{p}\right\rangle\right) \\
& K_{f, p}=-\frac{\left|\sum F_{p, f}\right|}{V_{c e l l}\left|u_{f}-\left\langle u_{p}\right\rangle\right|}
\end{aligned}
$$

여기서, 식 (5)의 $V_{c}$ 와 $V_{p, k}$ 는 셀의 부피와 셀에 위치한 $k$ 번째 입자의 부피를 각각 나타낸다. $N_{p}$ 는 셀에 위치한 입자 수를 나타낸다. 식 (6)의 $\nu_{f}$ 는 유체 동점성계수이고, $I$ 는 단위 텐서를 나타낸다. 식 (7)의 $K_{f, p}$ 는 유체-입자 상호작용 계수이고, $\left\langle u_{p}\right\rangle$ 는 셀 중심에서의 입자 속도를 나타낸다. 유체-입자 상호작용 계수는 식 (8)과 같이 나타낼 수 있다. 여기서, $V_{\text {cell }}$ 은 셀의 부피이며, $F_{p, f}$ 는 입자에 작용하 는 유체력을 의미한다. 입자에 작용하는 유체력은 항력과 점성력 그리고 부력을 고려하였다. 부력은 입자에 작용하는 압력 차이에 의한 힘으로 나타내었다. 따라서 각 셀에 위치한 입자들이 받는 유체력의 합을 계산하여 유체-입자 간 상호작용을 고려할 수 있다. 입자가 받는 유체력은 항력이 가장 지배적이며 Koch and Hill (2001)이 제시한 항력 모델을 이용하여 계산한다. Koch and Hill (2001)에 근거한 항력 관계는 식 (9)와 (10)에 나타난다. 여기서, $R e_{p}$ 는 입자에 대한 레이놀즈수를 의미하고 $R e_{p}=\left(\alpha_{f} \rho_{f}\left|u_{f}-u_{p}\right| d_{p}\right) / \mu_{f}$ 으로 정 의된다. 또한, $\alpha_{p}$ 는 셀에서 입자가 차지하는 부피비를 의미하며 $\alpha_{p}=1-\alpha_{f}$ 로 나타낼 수 있다. $F_{0}\left(\alpha_{p}\right)$ 는 $\alpha_{p}$ 의 기준 값(0.4)에 따라 식 (11)-(12)와 같이 정의된다. 


$$
\begin{aligned}
& F_{D}=\frac{V_{p} \beta}{\alpha_{p}}\left(u_{f}-u_{p}\right) \\
& \beta=\frac{18 \mu_{f} \alpha_{p} \alpha_{f}^{2}}{d_{p}^{2}}\left(F_{0}\left(\alpha_{p}\right)+0.5 F_{3}\left(\alpha_{p}\right) R e_{p}\right) \\
& F_{0}\left(\alpha_{p}\right)=\frac{1+3 \sqrt{0.5 \alpha_{p}}+(135 / 64) \alpha_{p} \ln \left(\alpha_{p}\right)+16.14 \alpha_{p}}{1+0.681 \alpha_{p}-8.48 \alpha_{p}^{2}+8.16 \alpha_{p}^{3}} \\
& F_{0}\left(\alpha_{p}\right)=\frac{10 \alpha_{p}}{\left(1-\alpha_{p}\right)^{3}} \quad \text { for } \alpha_{p} \geq 0.4 \\
& F_{3}\left(\alpha_{p}\right) \text { 는 식 }(13) \text { 과 같이 정의된다. } \\
& F_{3}\left(\alpha_{p}\right)=0.0673+0.212 \alpha_{p}+\frac{0.0232}{\left(1-\alpha_{p}\right)^{5}}
\end{aligned}
$$

개별 입자에 작용하는 항력은 입자 중심에서의 상대 속도를 이용한다. 이때, 유체 속도는 각 셀에서 산정한 유체 속도를 대 입하거나 입자 중심으로 보간(Interpolation)하여 개별 입자의 위 치에 따라 유체력을 산정한다. 본 연구에서는 각 셀에서 산정한 유체 속도를 입자 중심으로 보간하여 유체력을 적용하였다.

\section{3. 수치 해석 방법}

\subsection{CFD-DEM 연계기법}

본 연구에서 사용되는 CFD-DEM 알고리즘은 전산유체해석을
위한 격자 크기가 이산요소법에서 계산하는 입자의 크기보다 큰 특징을 가지고 있다. 이는 다량으로 밀집해있는 입자를 해석 하는 데 있어서 계산 비용과 정확도 측면에서 효율적이다. Fig. 1은 CFD-DEM 알고리즘의 계산 순서를 나타낸다. 먼저, 이산요 소해석 솔버(Solver)에서 초기화된 정보를 바탕으로 입자들의 위치, 속도 정보 등을 계산하여 전산유체해석 솔버로 넘겨준다. 전산유체해석 솔버에서는 각 격자 셀에 위치한 입자의 중심 좌 표를 바탕으로 각 셀에서 입자가 차지하는 부피비 $\left(\alpha_{p}\right)$ 를 계산 한다. 이때 개별 입자들의 속도는 해당 셀에서 차지하는 부피비 만큼 가중되어 계산되고, 이를 평균하여 셀 중심에서 속도 값 $\left(\left\langle u_{p}\right\rangle\right)$ 을 구한다. 셀 중심에서의 상대 속도 $\left(u_{f}-\left\langle u_{p}\right\rangle\right)$ 와 개별 입자가 셀에서 차지하는 부피비만큼 가중하여 개별 입자에 작 용하는 유체력을 이산요소해석 솔버로 넘겨준다. 이는 이산요 소해석 솔버에서 다음 시간 간격에서의 입자 거동을 해석하기 위해 저장된다. 계산된 입자 속도 $\left(u_{p}\right)$ 와 상호작용 계수 $\left(K_{f, p}\right)$ 그 리고 이전 단계에서의 유체 속도 $\left(u_{f}\right)$ 를 바탕으로 전산유체해석 솔버의 운동량 방정식을 계산하여 유체 흐름을 계산한다. 위의 과정들이 최종 계산 시간에 도달할 때까지 반복된다.

\section{2 계산영역, 경계조건과 격자 생성}

Fig. 2는 CFD-DEM 연계 해석이 적용되는 계산영역의 크기, 경계조건 그리고 격자를 보여준다. 전체 계산영역은 직사각형 형태이며 해저 지반에 해당하는 영역을 확장하여 구성하였다. 계산영역 전체 길이는 $17 \mathrm{D}$ 이며, 모노파일 중심에서 입구면 쪽 으로 $7 \mathrm{D}$, 출구면 쪽으로 $10 \mathrm{D}$ 로 설정하였다. 모노파일로부터 측 면 경계면까지의 폭은 $7 \mathrm{D}$, 해저 지반 표면 정상경계면 사이의 거리, 즉 수심은 $4 \mathrm{D}$ 로 계산하였다. 여기서 $\mathrm{D}$ 는 모노파일 직경 을 의미한다. 입구 경계면에 속도, 난류는 Dirichlet 조건, 압력은

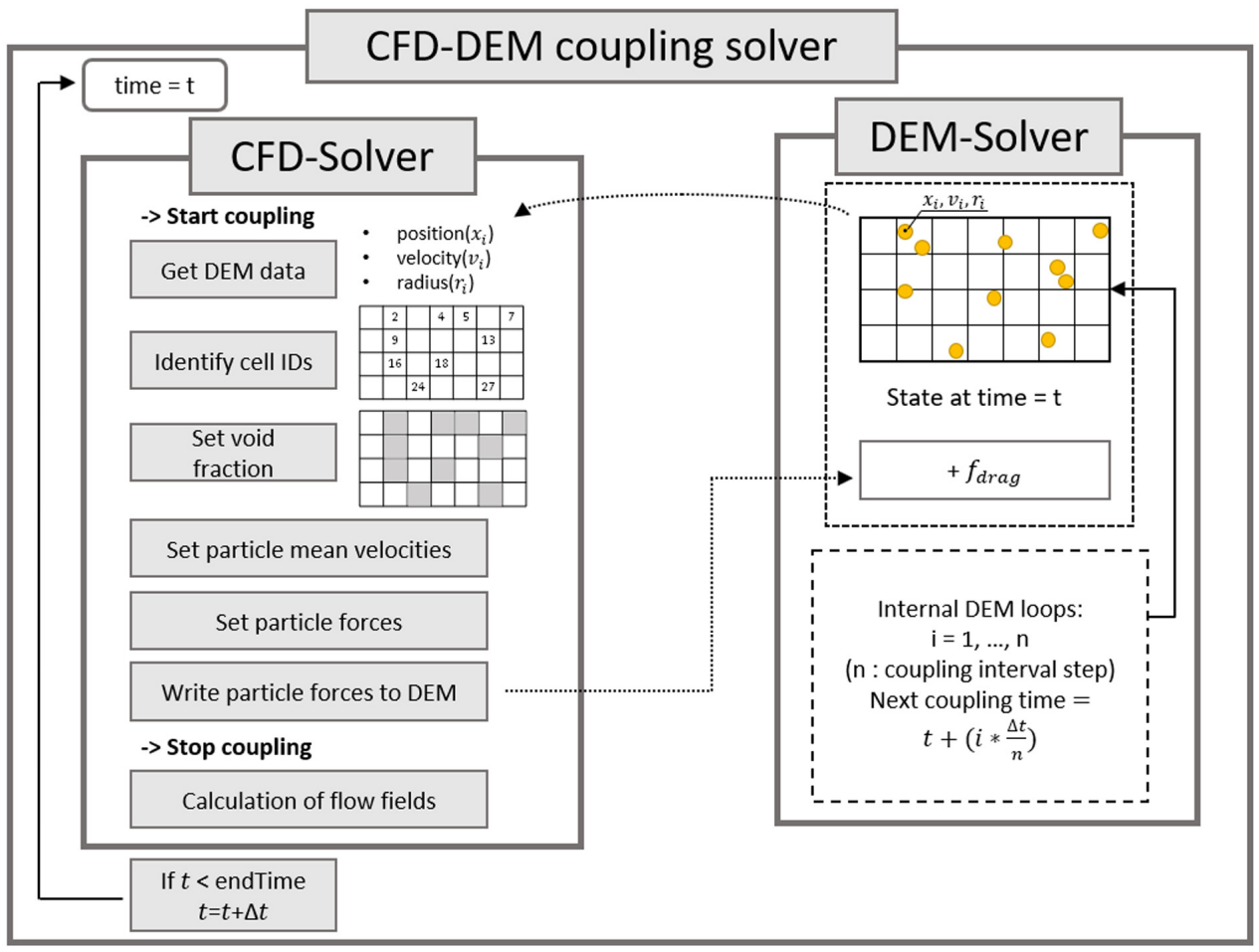

Fig. 1 CFD-DEM coupling algorithm 


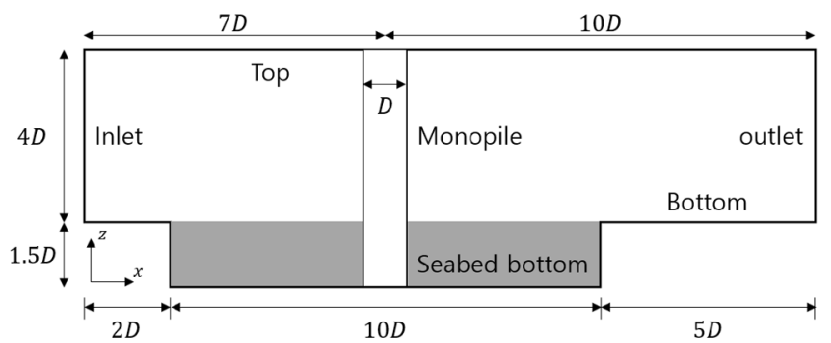

Fig. 2 Domain size, boundary conditions and mesh for CFD solver

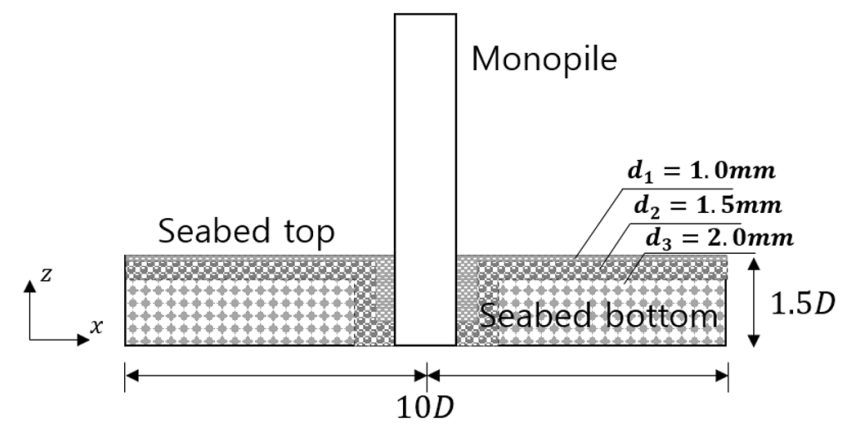

Fig. 3 Particle distribution and domain size for DEM solver

Neumann 조건을 설정하였다. 이와 반대로, 출구 경계면에서는 속도, 난류는 Neumann 조건, 압력은 Dirichlet 조건으로 설정하 였다. 모노파일 중심으로 물리현상을 대칭으로 가정하고 절반 만 해석하였다. 중앙 단면은 Symmetry 조건을 설정하였고 모노 파일 표면은 No-slip 조건으로 고려하였다.

이산요소해석을 위한 개별 입자의 초기 분포와 계산영역의 크기 는 Fig. 3 에 나타난다. 해저 지반을 구성하는 계산영역의 길이는 $10 \mathrm{D}$ 로 설정하였고, 모노파일 중심으로부터 입구 방향과 출구 방향 의 길이는 $5 \mathrm{D}$ 로 같다. 또한 벽면 효과를 최소화하기 위해 해저 지반의 폭과 깊이는 각각 $5 \mathrm{D}, 1.5 \mathrm{D}$ 로 계산하였다. 계산영역의 경계 면은 입자와 상호작용하지 않고 고정된 벽면 조건을 설정하여 유 체 흐름에 의해 움직이는 입자의 손실을 방지하였다. 해저 지반을 구성하는 입자는 구 모양으로 나타내었고, 입자 크기는 3 가지로 분포하였다. 해저 지반 표면과 모노파일에 의해 교란된 유체 흐름 이 지배적인 영역에는 $1 \mathrm{~mm}\left(d_{1}\right)$ 과 $1.5 \mathrm{~mm}\left(d_{2}\right)$ 크기의 입자를 차례 로 분포하고, 교란된 흐름과의 상호작용이 미미한 영역에는 $2 \mathrm{~mm}$ $\left(d_{3}\right)$ 로 분포하였다. 격자 생성은 OpenFOAM이 제공하는 자동 격자 생성 유틸리티인 BlockMesh와 SnappyHexMesh를 이용하여 비정렬 격자로 격자를 생성하였다. 유체 흐름과 해저 지반의 상호작용을 정확히 고려하기 위해 해저 지반 표면과 모노파일 주위에 상대적 으로 격자를 밀집시켰다. 가장 작은 입자 $\left(d_{1}\right)$ 가 분포되어 있는 영 역의 격자 크기를 입자 $\left(d_{1}\right)$ 의 약 3 배로 설정하였고 이는 많은 수치 해석 결과로부터 검증된 범위 $[2 d, 4 d]$ 에 해당한다(Xu et al., 2018). 여기서 $d$ 는 평균 입자 크기를 의미한다.

\section{4. 해석 결과 및 고찰}

\section{1 계산 조건}

본 연구는 CFD-DEM 연계기법을 이용한 모노파일 주위 모래 입자의 거동과 세굴 현상에 대한 연구이다. 표사 이동을 구현하
기 위해 입자의 초기 운동을 검증하였다. 세굴에 대한 수치해석 결과는 Roulund et al.(2005)의 실험 결과와 비교하였다. Fig. 4는 해석에 사용되는 문제와 주요 변수를 나타낸다. 수심 $(h)$ 과 경계 층 두께 $(\delta)$ 는 각각 $4 \mathrm{D}$ 와 $2 \mathrm{D}$ 이다. 본 연구에서는 모노파일 직경 을 실험 조건 $(0.1 \mathrm{~m})$ 보다 작은 $0.04 \mathrm{~m}$ 로 설정하였고, 수심 평균 유속(Mean flow velocity)은 $1.15 \mathrm{~m} / \mathrm{s}$ 이다. 모노파일 직경을 기준으 로 레이놀즈수 $\left(R e_{D}\right)$ 와 경계층 두께 기준 레이놀즈수 $\left(R e_{\delta}\right)$ 는 각 각 $R e_{D}=4.6 \times 10^{4}, R e_{\delta}=9.2 \times 10^{4}$ 에 해당하며, 이는 Roulund et al. (2005)의 조건과 동일하다. Roulund et al.(2005)의 모노파일 중심 에서의 속도 분포를 재현하기 위해 입구 경계면에 로그형 속도 분포를 초기조건으로 설정하였다. 파랑의 영향은 고려하지 않았 다. 해저 지반을 구성하는 모래 입자는 모노파일 주위에 분포한 다. 개별 입자로 모델링한 모래 입자는 해저 지반을 투과성 지반 으로 나타낼 수 있고, 투과성 지반 내의 유동은 CFD-DEM 연계 기법의 양방향 연성을 통해 $\mathrm{CFD}$ 로 해석한다. Table 1은 입자 정 보와 계산 조건을 나타낸다. 모래 입자의 밀도는 $2,650 \mathrm{~kg} / \mathrm{m}^{3}$ 이다. 본 연구에서 사용된 가장 작은 입자 크기는 $1 \mathrm{~mm}$ 이며, 이는 실험 에서 사용된 평균 입자 크기 $\left(d_{50}=0.26 \mathrm{~mm}\right)$ 보다 크다. 전체 입자 수는 약 130 만 개가 사용되었다. CFD-DEM 연계기법은 전산유 체해석 시간 간격이 이산요소해석 시간 간격보다 큰 특징을 가 지고 있다. 전산유체해석과 이산요소해석 시간 간격은 각각

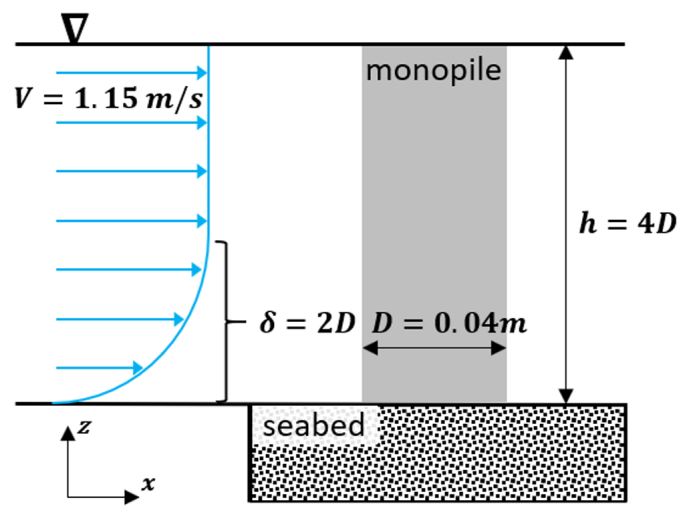

Fig. 4 Problem description

Table 1 Summary of Simulation Parameters

\begin{tabular}{lc}
\hline \multicolumn{2}{c}{ Spherical particles } \\
Number of particles & $1,300,000$ \\
Diameter [mm] & \\
present & $1,1.5,2$ \\
Roulund et al.(2005) & 0.26 \\
Density [kg/m $\left.\mathrm{m}^{3}\right]$ & 2,650 \\
Poisson's ratio & 0.35 \\
Young's modulus $\left[\mathrm{N} / \mathrm{m}^{2}\right]$ & $5 \times 10^{6}$ \\
Coefficient of friction & 0.6 \\
\hline \multicolumn{2}{c}{ Computation condition } \\
CFD time step [s] & $5 \times 10^{-4}$ \\
DEM time step [s] & $5 \times 10^{-6}$ \\
CFD-DEM coupling step & 100 \\
\hline
\end{tabular}


$5 \times 10^{-4} \mathrm{~S}, 5 \times 10^{-6} \mathrm{~s}$ 이다. 이는 이산요소해석 계산 간격의 100 번 째마다 전산유체해석과 이산요소해석 연계가 이루어진다는 것 을 의미한다. 즉, 입자에 작용하는 유체력은 전산유체해석 시간 간격마다 이산요소해석 솔버로 한 번만 전달되고, 이산요소해석 솔버에서 입자의 운동을 100 번 계산하여 전산유체해석 솔버로 입자 정보를 전달한다.

\section{2 입자 초기 운동(Incipient motion of the particle) 검증}

표사 이동을 구현하기 위해 토사 입자의 초기 운동에 대한 검 증을 수행하였다. 토사의 초기 운동은 입자에 작용하는 유체력 이 입자의 수중 무게와 입자 간의 저항력의 합보다 클 때 발생 한다. 입자 초기 운동의 판단은 임계치를 정의하는 변수에 따라 두 가지로 접근할 수 있다. 입자에 작용하는 유체 속도와 전단 력으로 나뉜다. 본 연구에서는 입자의 초기 운동 검증을 위해 임계치 속도를 사용하였다. 지름 $1 \mathrm{~mm}$ 인 입자가 길이 $4 D$, 폭 $1 D$, 깊이 $0.25 D$ 인 계산영역에 조밀하게 분포되어 있다. 유체는 높이 $4 D$ 의 입구 경계면에서 로그형 속도 분포로 유입되며, 식 (14)와 같이 표현된다.

$$
\frac{u}{U_{f}}=\frac{1}{\kappa} \ln \left(30 \frac{z}{k_{s}}\right)
$$

여기서, $z$ 는 해저 지반 표면으로부터 수직 거리를 의미하고, 등 가거칠기(Nikuradse's equivalent sand roughness)인 $k_{s}$ 는 $2.5 d_{p}$ 로 나타내었고, $\kappa$ 는 von Karman 상수를 의미한다. $U_{f}$ 는 마찰 속도 를 의미하고 $U_{f}=\kappa U_{\infty} / \ln \left(30 \delta / k_{s}\right)$ 으로 정의된다(Trygsland, 2015). 여기서 $U_{\infty}$ 는 유입 속도, $\delta$ 는 경계층 두께를 의미한다.

본 연구에서 사용한 CFD-DEM 연계기법은 입자 표면에 작용 하는 유체력을 직접 계산하지 않고 셀 안에 위치한 입자들의 중심에서의 값들을 평균하여 셀 중심에서 유체력을 산정한다. (a) $t_{0}$

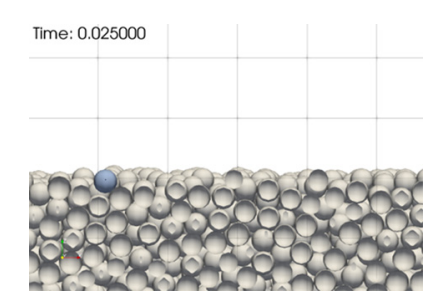

\section{Time: 0.075000}

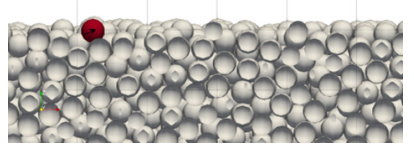

(b) $t_{0}+\Delta t$

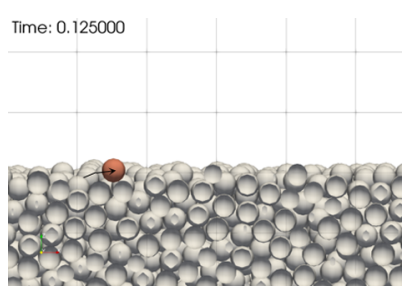

(c) $t_{0}+2 \Delta t$ Time: 0.175000

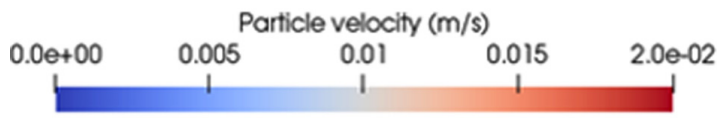

Fig. 5 Snapshots of particle locations during the incipient motion of a particle
따라서 초기조건은 입자 표면 거칠기를 고려한 속도 분포를 사 용하였지만 입자 중심에서 작용하는 유체력을 계산하여 입자의 초기 운동을 판단하였다. 입자의 초기 움직임에 대한 검증을 위 해 유입 속도와 임계치 속도의 비 $\left(V / V_{c}\right)$ 를 계산하였다. 여기에 서 $V_{c}$ 는 깊이 방향으로 속도 분포를 평균한 값을 의미한다. Fig. 5(a)는 유체력이 입자에 작용하기 시작하며, Fig. 5(b)에서 유체력 이 입자 저항력보다 커지면서 입자의 움직임이 발생한다. Fig. 5(c)와 Fig. 5(d)는 입자의 움직임을 연속적으로 보여준다(Ali and Dey, 2017). 유입 속도를 일정한 간격으로 증가하면서 입자들이 움직이기 시작하는 것을 확인하였고, 시각적인 이해를 돕기 위 해 특정 입자의 초기 움직임만 활성화하여 시간 변화에 따른 속 도를 Fig. 5에 나타내었다. 입자에 작용하는 유체의 속도가 $0.02 \mathrm{~m} /$ 가 되었을 때 입자의 초기 움직임이 발생하였다. 이때의 모노파일에 유입되는 평균 속도는 $0.92 \mathrm{~m} / \mathrm{s}$ 이고, 이를 통해 유입 속도와 임계치 속도의 비 $(V / V c)$ 가 1.25 로 계산되었다. 이는 Roulund et al.(2005)가 제시한 유입 속도와 임계치 속도의 비 $\left(\mathrm{V} / V_{c}\right)$ 인 1.25와 동일한 것을 확인하였다. 또한 부유한 토사가 다시 퇴적하고 이동하는 과정에서 침강 속도(Settling velocity)는 매우 중요한 영향을 미치며, 침강 속도에 따라 부유 및 퇴적의 경향과 정도가 결정된다(Lim and Son, 2016). 본 연구에서는 입 자에 작용하는 유체력의 합력에 의해 침강 속도가 결정된다.

\section{3 모노파일 주위 유체 흐름과 표사 이동}

모노파일 주위의 교란된 유체 흐름에 의해 입자는 후류 방향 으로 이동하고 지반은 침식된다. 침식된 해저 지반은 유체 흐름 에 영향을 주며 상호작용을 일으킨다. 이러한 일련의 세굴 발생 과정은 해석 결과에서 확인할 수 있다. Fig. 6은 해저 지반 정상 에서 $z / D=0.25$ 만큼 떨어진 단면에서의 진행 방향 속도 분포 를 시간에 따라 나타낸다. 가속된 유체 영역에서 해저 입자는 침식되고 후류 방향으로 이동할 것을 예측할 수 있다. 또한 모 노파일 뒤로 입자들이 퇴적되면서 유체 흐름에 영향을 주는 것 을 확인할 수 있다. 이러한 상호작용은 Park et al.(2017)에서는 예측하기 힘든 부분이다. 세굴의 깊이에 가장 영향을 주는 요소 는 모노파일을 타고 내려오는 하강류(Down flow)이다. Fig. 7은 $z / D=0.25$ 만큼 떨어진 단면에서의 수직 방향으로의 속도 분 포를 시간에 따라 나타낸다. 시간 흐름에 따라 커지는 하강류의

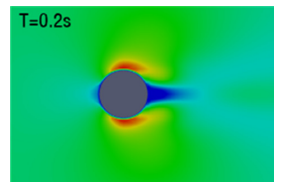

(a) $T=0.2 \mathrm{~s}$

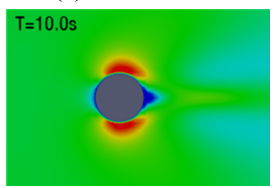

(d) $T=10.0 \mathrm{~s}$

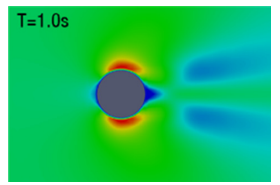

(b) $T=1.0 \mathrm{~s}$

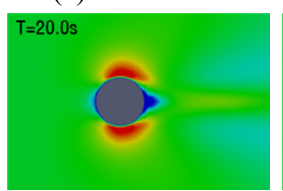

(e) $T=20.0 \mathrm{~s}$

Ux

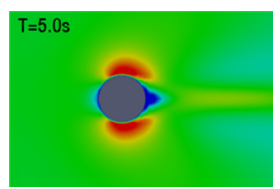

(c) $T=5.0 \mathrm{~s}$

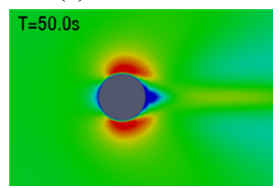

(f) $T=50.0 \mathrm{~s}$

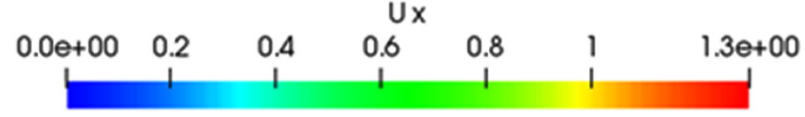

Fig. 6 X-direction velocity contours at $z / D=0.25$ 


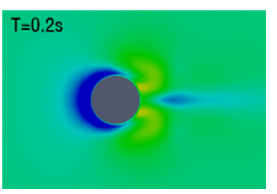

(a) $T=0.2 \mathrm{~s}$

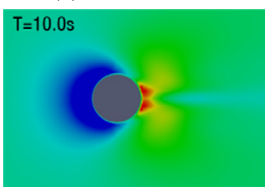

(d) $T=10.0 \mathrm{~s}$

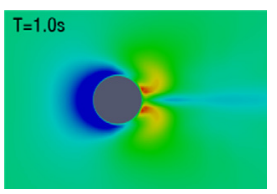

(b) $T=1.0 \mathrm{~s}$

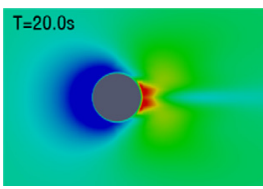

(e) $T=20.0 \mathrm{~s}$

$\mathrm{Uz}$

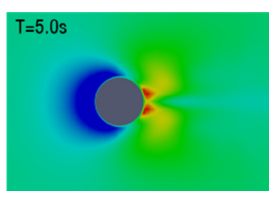

(c) $T=5.0 \mathrm{~s}$

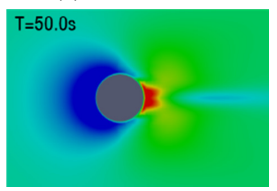

(f) $T=50.0 \mathrm{~s}$

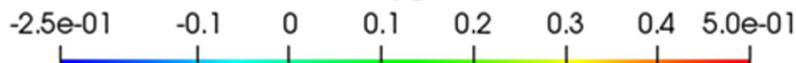

Fig. 7 Z-direction velocity contours at $z / D=0.25$

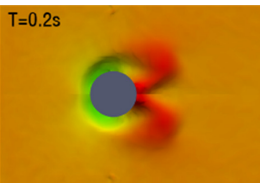

(a) $T=0.2 \mathrm{~s}$

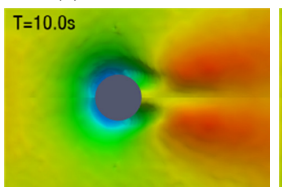

(d) $T=10.0 \mathrm{~s}$

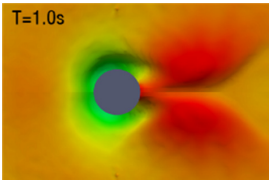

(b) $T=1.0 \mathrm{~s}$



(e) $T=20.0 \mathrm{~s}$

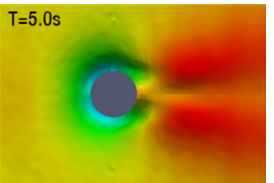

(c) $T=5.0 \mathrm{~s}$

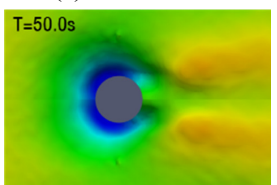

(f) $T=50.0 \mathrm{~s}$ bed surface elevation $\mathrm{z} / \mathrm{D}$



Fig. 8 Bed surface elevation at $z / D$ with volume fraction $\alpha_{f}=0.7$

영역을 통해 세굴 영역을 예측할 수 있다.

Fig. 8은 유체 흐름과 입자의 상호작용에 의해 변화된 해저 지반을 시간 변화에 따라 나타낸 것이다. 해저 지반의 높이는 $z / D$ 로 나타내었다. 모노파일 측면에서 침식이 발달하면서 모 노파일 뒤로는 퇴적물이 쌓여 언덕 모양을 형성한다. 시간의 경 과에 따라 세굴 깊이와 폭이 증가하고 언덕 모양의 퇴적물은 후류 방향으로 이동한다. 이러한 지반 형태의 변화는 유체 흐름 의 변화를 야기한다.

Fig. 9는 모노파일 전방에서 해저 지반의 높이 변화를 시간에 따라 나타내었다. 일반적으로 세굴의 깊이는 특정 시간 동안 두 드러지게 변화하고, 특정 시간이 지나면 평형상태로 나아간다. 세굴의 평형상태라 함은 세굴공(Scour hole)에서 유출되는 토사 량이 상류로부터 유입되는 토사량과 동일하여 세굴공이 평형상 태가 되고 이때의 세굴 깊이를 의미한다. Fig. 9에서 55.0s를 지 나 세굴공의 변화가 현저히 감소하는 것을 확인할 수 있다. 본 연구에서는 $55.0 \mathrm{~s}$ 를 기점으로 세굴의 깊이 변화가 없다고 간주 하였고, 이때 평형상태의 세굴 깊이는 약 -1.0 으로 예측된다. 본 연구에서 수행한 수치 모의 계산과 비교 검증을 수행한 Roulund et al.(2005)의 실험에 대한 제원 및 결과를 Table 2에 비교 정리하였다. 본 연구에서 실험 조건에 비해 모노파일 직경 은 더 작고 입자 크기는 더 크지만 구조물과 경계층에 대한 유

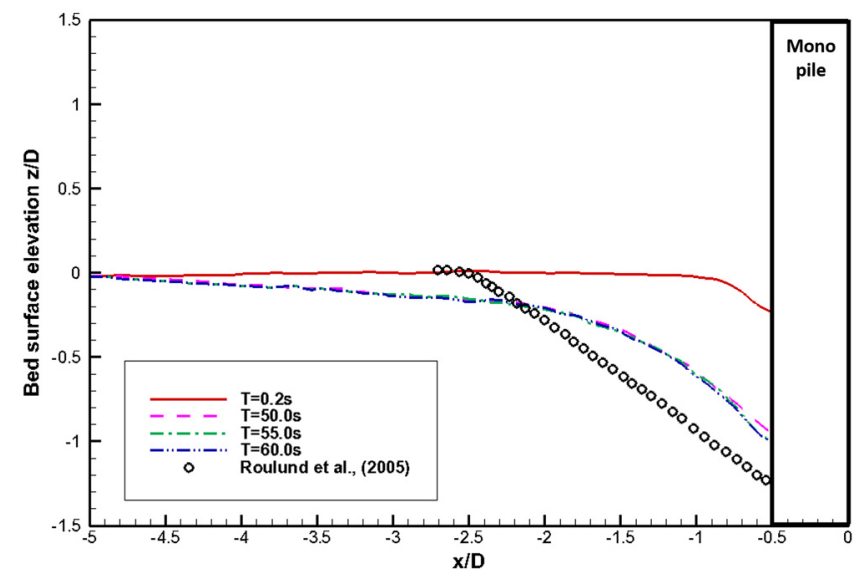

Fig. 9 Time evolution of the bed surface elevation at $z / D$ in front of the monopile

Table 2 Summary of Simulation Conditions and Results

\begin{tabular}{lcc}
\hline \hline & Present & $\begin{array}{c}\text { Roulund et al. } \\
(2005)\end{array}$ \\
\hline Water depth $h[\mathrm{~m}]$ & 0.16 & 0.4 \\
Boundary-layer thickness $\delta[\mathrm{m}]$ & 0.08 & 0.2 \\
Mean flow velocity $V[\mathrm{~m} / \mathrm{s}]$ & 1.15 & 0.46 \\
Monopile diameter $D[\mathrm{~m}]$ & 0.04 & 0.1 \\
$R e_{D}=V D / \nu$ & \multicolumn{2}{c}{$4.6 \times 10^{4}$} \\
$R e_{\delta}=V \delta / \nu$ & \multicolumn{2}{c}{$9.2 \times 10^{4}$} \\
$V / V_{c}$ & \multicolumn{2}{c}{1.25} \\
Equilibrium scour depth & $\approx 1.0$ & $\approx 1.23$ \\
\hline
\end{tabular}

체의 레이놀즈수는 동일하다. 또한, 입자 초기 운동에서 유입 속도와 임계치 속도의 비를 실험값과 동일하게 유지하였다 (Yang et al., 2018). 따라서 비교 검증을 위해 실험의 세굴 깊이 를 직접 비교하는 것은 타당하다. 모노파일 전방에서의 세굴 깊 이는 Roulund et al.(2005)의 실험값보다 약 $23 \%$ 차이가 나는 것 을 확인할 수 있다. 또한 모노파일 전방에서 해저 지반은 국부 적인 세굴영역 뿐만 아니라 전체적으로 침식되는 것을 보여준 다. 계산과 실험의 차이는 토사의 입도분포도와 액상화로 인한 세굴의 가속화가 고려되지 않았기 때문으로 여겨진다. 또한, 계 산 부하와 관련된 입자 크기의 제한 및 계산영역의 크기가 영 향을 준 것으로 여겨진다.

\section{5. 결 론}

해류에 노출된 모노파일 주위의 유체 흐름과 모래 입자의 거 동을 연구하였다. 해저 지반을 구성하는 모래 입자와 유체 흐름 과의 상호작용을 해석하기 위해 오일러리안 기법의 전산유체역 학(CFD)과 라그랑지안 기법의 이산요소법(DEM)의 연계 방법을 사용하였다. 유체 해석을 위해 오픈소스 라이브러리인 오픈폼 (OpenFOAM) 솔버를 사용하였고, 입자 해석을 위해 LIGGGHTS 솔버가 사용되었다.

표사 이동을 구현하기 위해 입자의 초기 운동에 대한 해석을 
진행하였다. 유입 속도와 임계치 속도의 비를 실험 결과와 비교 하여 검증하였다. 유체속도와 임계치 속도의 비는 실험결과와 일치하였다. 연계된 해석 기법은 모노파일 주위의 유체 흐름과 입자의 거동 그리고 침식 작용까지 해석하였다. 계산된 세굴의 깊이 분포는 Roulund et al.(2005)의 실험 결과와 비교하였고, 해 석 결과에서 모노파일 전면 해저 지반의 세굴 현상에 대해 정 성적으로 재현이 가능하였다. 세굴 깊이의 정도가 약 $23 \%$ 과소 평가가 되었고, 이는 토사의 액상화 부재와 입자의 크기 및 입 도분포 그리고 계산영역의 가정으로 비롯되었다고 여겨진다.

본 연구에서는 CFD-DEM 연계기법을 활용하여 모노파일 주 위 세굴에 대한 정성적, 정량적 평가를 통해 세굴공의 넓이와 세굴 깊이에 대해 해석하였다. 이러한 결과는 고정식 지지구조 물의 설계와 세굴 보호 공법을 위한 자료로 고려될 수 있다. 향 후 토사의 액상화와 입자 크기에 따른 분포를 고려한 연구가 필요하다.

\section{후기}

본 연구는 한국연구재단(NRF-2015R1C1A1A02037577, NRF-2018 $\mathrm{R} 1 \mathrm{~A} 1 \mathrm{~A} 1 \mathrm{~A} 05020799)$ 의 지원을 받아 수행되었으며, 이에 감사드 립니다.

\section{References}

Ali, S.Z., Dey, S., 2017. Origin of the Scaling Laws of Sediment Transport. Proceedings of the Royal Society A: Mathematical, Physical and Engineering Sciences, 473(2197). https://doi.org/ 10.1098/rspa.2016.0785

Anderson, T., Jackson, R., 1967. A Fluid Mechanical Description of Fluidized Beds: Equations of Motion. Industrial \& Engineering Chemistry Fundamentals, 6(4), 527-539.

Baykal, C., Sumer, B.M., Fuhrman, D.R., Jacobsen, N.G., Fredsøe, J., 2017. Numerical Simulation of Scour and Backfilling Processes around a Circular Pile in Waves. Coastal Engineering, 122, 87-107.

Cundall, P.A., Strack, O.D., 1979. A Discrete Numerical Model for Granular Assemblies. Geotechnique, 29(1), 47-65.

Dargahi, B., 1989. The Turbulent Flow Field around a Circular Cylinder. Experiments in Fluids, 8(1-2), 1-12. https://doi.org/ 10.1007/BF00203058

Goniva, C., Kloss, C., Deen, N.G., Kuipers, J.A., Pirker, S., 2012. Influence of Rolling Friction on Single Spout Fluidized Bed Simulation. Particuology, 10(5), 582-591. https://doi.org/10. 1016/j.partic.2012.05.002

Hur, D.S., Jeon, H.S., 2011. Development of Numerical Model for Scour Analysis under Wave Loads in Front of an Impermeable Submerged Breakwater. Journal of The Korean Society of Civil Engineers, 31.

Kloss, C., Goniva, C., Hager, A., Amberger, S., Pirker, S., 2012. Models, Algorithms and Validation for Opensource DEM and
CFD-DEM. Progress in Computational Fluid Dynamics, an International Journal, 12(2-3), 140-152.

Koch, D.L., Hill, R.J., 2001. Inertial Effects in Suspension and Porous-media Flows. Annual Review of Fluid Mechanics, 33(1), 619-647. https://doi.org/10.1146/annurev.fluid.33.1.619

Li, J., Tao, J., 2018. CFD-DEM Two-Way Coupled Numerical Simulation of Bridge Local Scour Behavior under Clear-Water Conditions. Transportation Research Board 97th Annual Meeting (No. 18-05939), Washington, DC, USA.

Lim, B.G., Son, M., 2016. Study on Applicability of Fractal Theory to Cohesive Sediment in Small Rivers. Journal of Korea Water Resource Association, 49, 887-901. https://doi.org/10.3741/ JKWRA.2016.49.10.887

Pang, A.L.J., Skote, M., Lim, S.Y., Gullman-Strand, J., Morgan, N., 2016. A Numerical Approach for Determining Equilibrium Scour Depth around a Mono-pile Due to Steady Currents. Applied Ocean Research, 57, 114-124. https://doi.org/10.1016/ j.apor.2016.02.010

Park, S., Song, S., Whang, H. Joung, T., Shin, Y., 2017. Parametric Study on Scouring around Suction Bucket Foundation. Journal of Ocean Engineering and Technology, 31(4), 281-287. https://doi.org/10.26748/KSOE.2017.08.31.4.281

Roulund, A., Sumer, B.M., Fredsøe, J., Michelsen, J., 2005. Numerical and Experimental Investigation of Flow and Scour around a Circular Pile. Journal of Fluid Mechanics, 534, 351-401. https://doi.org/10.1017/S0022112005004507

Schmeeckle, M.W., 2014. Numerical Simulation of Turbulence and Sediment Transport of Medium Sand. Journal of Geophysical Research: Earth Surface, 119(6), 1240-1262. https://doi.org/ 10.1002/2013JF002911

Sumer, B.M., Fredsøe, J., 2002. The Mechanics of Scour in the Marine Environment. 17, World Scientific Publishing Company, Singapore.

Sun, R., Xiao, H., 2016. CFD-DEM Simulations of Current-induced Dune Formation and Morphological Evolution. Advances in Water Resources, 92, 228-239. https://doi.org/10.1016/ j.advwatres.2016.03.018

Trygsland, E., 2015. Numerical Study of Seabed Boundary Layer Flow around Monopile and Gravity-based Wind Turbine Foundations. Master's Thesis, NTNU, Trondheim, Norway.

Whitehouse, R., 1998. Scour at Marine Structures: A Manual for Practical Applications. Thomas Telford, London.

Xu, S.L., Sun, R., Cai, Y.Q., Sun, H.L., 2018. Study of Sedimentation of Non-cohesive Particles via CFD-DEM Simulations. Granular Matter, 20(1), 4. https://doi.org/10.1007/s10035-017-0769-7

Yang, J., Low, Y.M., Lee, C.H., Chiew, Y.M., 2018. Numerical Simulation of Scour around a Submarine Pipeline Using Computational Fluid Dynamics and Discrete Element Method. Applied Mathematical Modelling, 55, 400-416. https://doi.org/ 10.1016/j.apm.2017.10.007 